\title{
The Effect of Blood Volume Expansion on Gastrointestinal Oxygenation in Piglets
}

\author{
PHILIP T. NOWICKI, NANCY B. HANSEN, BARBARA S. STONESTREET, ALICE C. YAO, ${ }^{1}$ AND \\ WILLIAM OH \\ Department of Pediatrics, Women and Infants Hospital of Rhode Island and the Program in Medicine, Brown \\ University, Providence, Rhode Island 02908
}

\begin{abstract}
Regional and total gastrointestinal (GI) blood flow, $\mathrm{O}_{2}$ delivery, $\mathrm{O}_{2}$ extraction, and $\mathrm{O}_{2}$ consumption were measured before and after acute blood volume expansion in 2-day-old piglets. Blood flow was measured with radionuclide-labeled microspheres. Sixty minutes after a rapid transfusion of age- and hematocrit-matched piglet donor blood, ${ }^{51} \mathrm{Cr}$-measured blood volume increased $19 \%$ while an increase in hematocrit suggested plasma transudation to the extravascular space had occurred in response to blood volume loading. Following transfusion, total GI blood flow and $\mathrm{O}_{2}$ delivery did not change, although $\mathrm{O}_{2}$ extraction decreased by $31 \pm 4 \% . \mathrm{O}_{2}$ consumption by the GI tract decreased from $2.0 \pm 0.19 \mathrm{ml} \mathrm{O}_{2} \cdot \mathrm{min}^{-1} \cdot 100 \mathrm{~g}^{-1}$ to $1.46 \pm 0.24 \mathrm{ml} \mathrm{O}_{2} \cdot \mathrm{min}^{-1} \cdot 100 \mathrm{~g}^{-1} 1 \mathrm{~h}$ after transfusion. Feeding was then accomplished via orogastric tube to determine if animals stressed by blood volume loading would increase $\mathrm{GI} \mathrm{O}_{2}$ consumption in response to feeding. The postprandial increase in $\mathbf{G I} \mathrm{O}_{2}$ consumption was similar to that previously reported in newborn piglets. Therefore, in the fasting state, acute blood volume loading disrupts $\mathrm{GI} \mathrm{O}_{2}$ transport at the capillary level and decreases $\mathrm{GI} \mathrm{O}_{2}$ consumption. However, animals subjected to blood volume loading appear capable of increasing $\mathrm{GI} \mathrm{O}_{2}$ consumption after feeding. (Pediatr Res 19: 268-271, 1985)
\end{abstract}

Abbreviation

\section{GI, gastrointestinal}

Placental transfusion during parturition produces rapid intravascular volume expansion in the neonate, followed by plasma transudation and a shift of the volume load to the extravascular, or interstitial space $(3,19)$. These circulatory events are clinically expressed in several ways, including alterations in neonatal renal (18) and respiratory (19) function.

In the adult GI tract, volume loading with saline (13) or Tyrode's solution (1) results in a physical disruption of the interstitial space, due to increased capillary filtration which expands the interstitium and reverses direction of the net water flow from absorption to secretion. Because oxygenation of the GI tract is dependent, in large part, on regulation of $\mathrm{O}_{2}$ extraction at the capillary level $(6,7,21)$, it is conceivable that volume

Received March 12, 1984; accepted October 21, 1984.

Address for reprints William Oh, M.D., 50 Maude Street, Providence, RI 02908. Supported by the National Research Service Award 1 T32 HDO7232-01, National Institute of Child Health and Human Development, Bethesda, MD.

'Collaboration while on sabbatical leave from Downstate Medical Center, State University of New York, Brooklyn, NY. expansion, and consequent disruption of the interstitial space, might affect capillary hemodynamics and GI oxygenation. This study was designed to test the hypothesis that acute volume expansion with whole blood affects $\mathrm{GI} \mathrm{O}_{2}$ transport and consumption. Therefore, we measured $\mathrm{GI}$ blood flow, $\mathrm{O}_{2}$ delivery, $\mathrm{O}_{2}$ extraction, and $\mathrm{O}_{2}$ consumption before and after rapid whole blood transfusion in newborn piglets. Feeding increases the oxidative requirements and $\mathrm{O}_{2}$ consumption of the GI tract $(2,4$, 17). To determine if blood volume affected the ability of the GI tract to increase $\mathrm{O}_{2}$ consumption in response to feeding, we also studied the transfused piglets following a test meal of artificial pig milk.

\section{MATERIALS AND METHODS}

Animal preparation. Twenty-four hours before study, seven 2day-old piglets were catheterized under nitrous oxide and $1 \%$ xylocaine anesthesia. Catheters were placed in the left ventricle via the right carotid artery, superior vena cava via the right jugular vein, abdominal aorta via the left femoral artery, and the portal vein, via the common umbilical vein. The portal vein catheter can be used to accurately measure the $\mathrm{O}_{2}$ content of the venous drainage of the piglet GI tract (17). The piglets received intravenous ampicillin $(100 \mathrm{mg} / \mathrm{kg})$, kanamycin $(5 \mathrm{mg} / \mathrm{kg}), 5 \%$ dextrose in water $(10 \mathrm{ml} / \mathrm{kg}$ given over $30 \mathrm{~min})$, and then the catheters were filled with heparin $(250 \mathrm{U} / \mathrm{ml})$ and secured. Postoperatively, thermal environment was maintained at $38^{\circ} \mathrm{C}$ and orogastric gavage feedings were administered using artificial pig milk (Land-O-Lakes Co., Minneapolis, MN), $30 \mathrm{ml} / \mathrm{kg}$ every 3 $\mathrm{h}$; feedings were stopped $8 \mathrm{~h}$ before the study. The artificial pig milk contained: total protein $28 \%$, total fat $10 \%$, total lactose $4 \%$, and is similar in composition to natural pig milk. At the time of the study all animals had recovered from surgery and body weight was unchanged or increased compared to preoperative weight.

Experimental protocol. During the study the animals were awake and unrestrained. The study consisted of five measurement periods. During each period, blood flow, cardiac output, arteriovenous $\mathrm{O}_{2}$ content difference, arterial blood gas, and hematocrit determinations were made. In addition, during the first, second, and final periods, blood volume determinations were made. The study sequence was as follows. A baseline, pretransfusion measurement was made, and then the animal was administered a sufficient volume of whole blood through the superior vena cava catheter over $1 \mathrm{~min}$ to increase pretransfusion blood volume by $26-28 \%$. This degree of blood volume expansion was chosen as it represents an increment similar in magnitude to that which follows placental transfusion in human infants (22). The transfused blood was obtained from an age- and hematocrit $( \pm$ $5 \%$ )-matched piglet donor. Sixty minutes after transfusion, meas- 
urements were repeated. The animal was then fed $30 \mathrm{ml} / \mathrm{kg}$ of pig formula via orogastric tube over $5 \mathrm{~min}$. Measurements were repeated 30,60 , and 120 min after feeding and then the animal was euthanized with pentobarbital.

Methodology. Blood flow and cardiac output were measured with microspheres, $15 \pm 2$ microns in diameter, labeled with one of five radionuclides: ${ }^{113} \mathrm{Sn},{ }^{46} \mathrm{Sc},{ }^{95} \mathrm{Nb},{ }^{57} \mathrm{Co},{ }^{103} \mathrm{Ru}$ (New England Nuclear, Inc., Boston, MA). Approximately $9 \times 10^{5}$ microspheres suspended in $1.2 \mathrm{ml}$ of $10 \%$ Dextran and $0.01 \%$ Tween were continuously agitated and injected into the left ventricle over 30 $\mathrm{s}$ and the catheter flushed with $3 \mathrm{ml} 0.9 \%$ saline. A reference arterial blood sample was withdrawn from the descending aorta at a constant flow rate of $1.03 \mathrm{ml} / \mathrm{min}$ beginning $10 \mathrm{~s}$ before microsphere injection and lasting $120 \mathrm{~s}$. Following each blood withdrawal, blood replacement with age-matched piglet blood was performed $(3 \mathrm{ml}$ of whole blood over $1 \mathrm{~min}$ through the superior vena cava catheter).

The position of all catheters were verified at autopsy. Tissue preparation was accomplished as previously described (17) allowing determination of total and regional GI blood flows and cardiac output. Radioactivity of reference blood and tissue or ash specimens were measured with a $\gamma$ scintillation spectrometer. Regional blood flows were obtained using a Digital PdP-11/34 computer (Digital Equipment, Maynard, MA) which corrects for specimen composition, isotope decay, and spillover. Regional blood flows were calculated with the equation (9):

$$
\text { organ blood flow }=\frac{\mathrm{cpm} \text { organ }}{\mathrm{cpm} \text { reference blood }} \times \begin{gathered}
\text { rate of withdrawal } \\
\text { reference blood }
\end{gathered}
$$

All blood and tissue specimens contained sufficient microspheres to assure accuracy of blood flow determinations to within $5 \%$ (9) and in no case was any change in blood pressure or heart rate observed as a result of microsphere injection. Those factors shown responsible for migration of previously trapped microspheres in GI tissue (16) were not present during the study.

Red cell mass was measured with ${ }^{51} \mathrm{Cr}$-labeled autologous red blood cells and blood volume calculated from simultaneously obtained hematocrits (14). Blood specimens were assayed for radioactivity using a $\gamma$ scintillation spectrometer (Packard Autogamm Scintillation Spectrometer, Packard Instruments, Downes Grove, IL). Preliminary studies revealed that triplicate red cell mass determinations could be performed in each animal with excellent reproducibility $( \pm 1.8 \%)$.

Arterial blood gas measurements were obtained with a Corning Blood Gas Analyzer 175 (Corning Scientific, Medford, MA) and $\mathrm{O}_{2}$ contents measured in duplicate with a Lex- $\mathrm{O}_{2}$-Con (Lexington Instruments, Waltham, MA). Heart rate and mean arterial blood pressure were measured before and after each microsphere injection using a Hewlett-Packard transducer and recorded on a Hewlett-Packard polygraph model 775A (Hewlett-Packard Co., Lexington, MA).

Data analysis. $\mathrm{O}_{2}$ delivery, extraction, and consumption were derived using the Fick principle: $\mathrm{O}_{2}$ delivery $\left(\dot{\mathrm{DO}}_{2}\right)=$ blood flow $(\dot{\mathrm{Q}}) \cdot \operatorname{arterial} \mathrm{O}_{2}$ content $\left(\mathrm{CaO}_{2}\right) ; \mathrm{O}_{2}$ consumption $\left(\dot{\mathrm{VO}}_{2}\right)=\dot{\mathrm{Q}}$.
$\left[\mathrm{CaO}_{2}-\right.$ portal vein $\mathrm{O}_{2}$ content $\left.\left(\mathrm{CpvO}_{2}\right)\right] ; \mathrm{O}_{2}$ extraction $=\mathrm{V}_{2} /$ $\mathrm{DO}_{2}=\left(\mathrm{CaO}_{2}-\mathrm{CpvO}_{2}\right) \cdot \mathrm{CaO}_{2}^{-1}$.

Blood flow is expressed as $\mathrm{ml} \cdot \mathrm{min}^{-1} \cdot 100 \mathrm{~g}^{-1}$ tissue weight and cardiac output as $\mathrm{ml} \cdot \mathrm{min}^{-1} \cdot \mathrm{kg}^{-1}$ body weight. $\dot{\mathrm{DO}}_{2} \mathrm{GI}$ and $\dot{\mathrm{VO}}_{2} \mathrm{GI}$ are expressed as $\mathrm{ml} \mathrm{O}_{2} \cdot \mathrm{min}^{-1} \cdot 100 \mathrm{~g}^{-1}$ tissue weight. Data are expressed as mean \pm SEM.

Data analysis was performed using a blocked one-way ANOVA for repetitive measures and Dunnett's posthoc test. Two separate analyses were carried out. First, the 60 -min posttransfusion measurement was analyzed using the pretransfusion measurement as baseline. Second, the three postprandial measurements were analyzed using the 60 -min posttransfusion measurement as fasting baseline.

\section{RESULTS}

As shown in Table 1, transfusion resulted in an increase $(p<$ 0.05 ) in mean arterial blood pressure, but did not alter heart rate. These variables did not change after feeding. Blood volume increased $19 \% 60$ min following transfusion $(p<0.05)$; smaller, but significant increases were noted in hematocrit and $\mathrm{CaO}_{2}(p$ $<0.05$ ). Values for blood volume, hematocrit, and $\mathrm{CaO}_{2}$ all declined in the final measurement (120 min after feeding).

One hour after transfusion, cardiac output decreased $(p<$ 0.05 ), although total GI blood flow (QGI) and regional blood flow to the stomach, proximal and distal small bowel, and colon did not change significantly (Figs. 1 and 2). After feeding, both $\mathrm{CO}$ and $\mathrm{Q} G \mathrm{I}$ increased $(p<0.05)$. The postprandial hyperemia persisted until 60 min after the meal. Regionally, this hyperemia was localized to the proximal and distal small bowel, as no change was noted in blood flow to the stomach or colon.

Gl oxygenation data are shown in Figure 3. One hour after transfusion, $\mathrm{GI} \mathrm{O}_{2}$ delivery $\left(\mathrm{DO}_{2} \mathrm{GI}\right)$ did not change, whereas $\mathrm{GI}$ $\mathrm{O}_{2}$ extraction and $\mathrm{GI} \mathrm{O}_{2}$ consumption $\left(\mathrm{VO}_{2} \mathrm{GI}\right)$ both decreased $(p<0.05)$. After feeding, $\mathrm{DO}_{2} \mathrm{GI}$ and $\mathrm{GI} \mathrm{O}_{2}$ extraction appeared to increase, but the large standard errors generated by these data

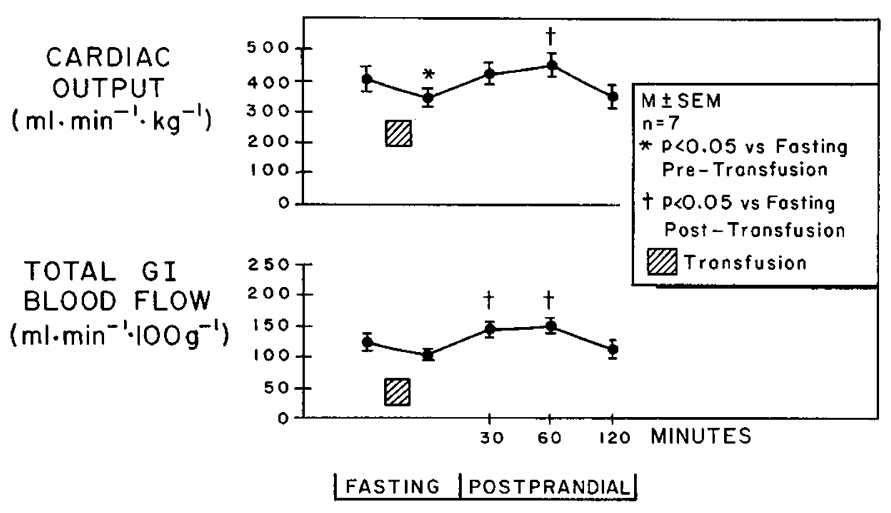

Fig. 1. Cardiac output and total GI blood flow.

Table 1. Transfusion results*

\begin{tabular}{|c|c|c|c|c|c|}
\hline & \multicolumn{2}{|c|}{ Fasting } & \multicolumn{3}{|c|}{ Postprandial (min) } \\
\hline $\begin{array}{l}\text { Mean arterial blood pres- } \\
\text { sure }(\mathrm{mm} \mathrm{Hg})\end{array}$ & $65 \pm 3$ & $78 \pm 4 \dagger$ & $80 \pm 5$ & $80 \pm 4$ & $76 \pm 3$ \\
\hline Heart rate (bpm) & $238 \pm 17$ & $212 \pm 18$ & $228 \pm 18$ & $209 \pm 14$ & $223 \pm 16$ \\
\hline Blood volume $(\mathrm{ml} / \mathrm{kg})$ & $81.4 \pm 3.0$ & $95.1 \pm 3.5 \dagger$ & & & $84.8 \pm 3.3$ \\
\hline Hematocrit (\%) & $27 \pm 1$ & $31 \pm 1 \dagger$ & $30 \pm 2$ & $29 \pm 1$ & $28 \pm 1$ \\
\hline
\end{tabular}

${ }^{*}$ Mean $\pm \mathrm{SEM}, \mathrm{n}=7$.

$\dagger p<0.05$ versus pretransfusion. 


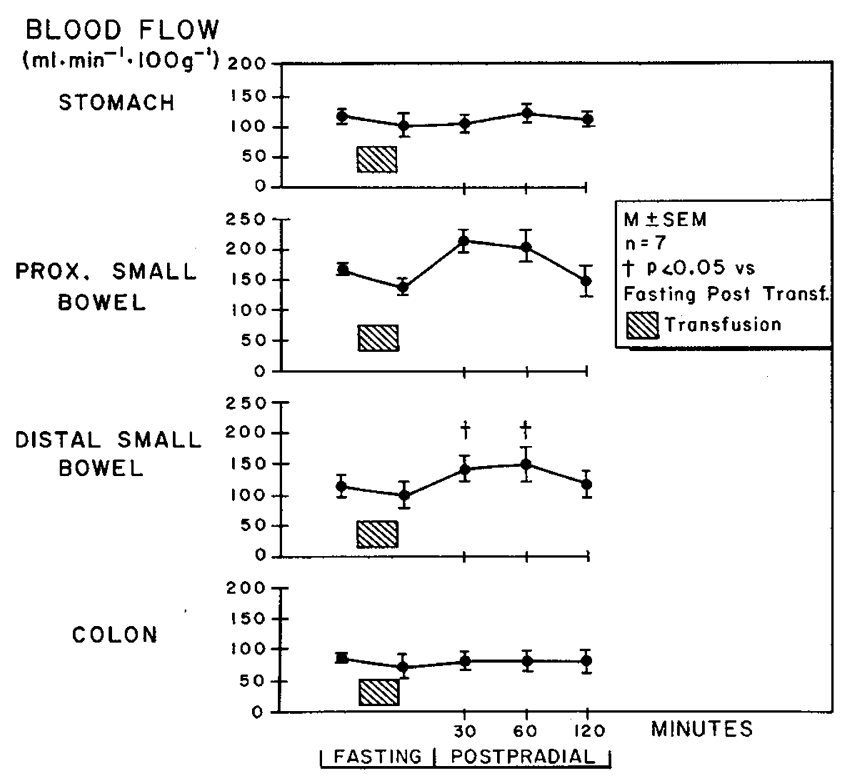

Fig. 2. Regional blood flow to stomach, proximal and distal small bowel, and colon.

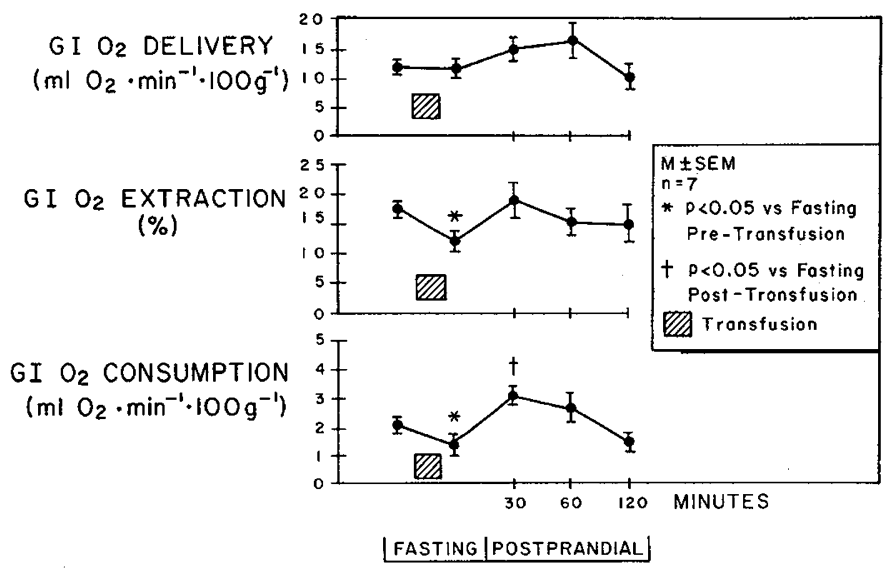

Fig. 3. $\mathrm{GI} \mathrm{O}_{2}$ delivery, $\mathrm{O}_{2}$ extraction, and $\mathrm{O}_{2}$ consumption.

precluded the statistical significance of these changes. Thirty minutes after feeding $\mathrm{VO}_{2} \mathrm{GI}$ did significantly increase $(p<0.05)$.

\section{DISCUSSION}

The purpose of this study was to simulate the circulatory consequences of placental transfusion. In the human neonate, placental transfusion results in hypervolemia, followed by compensatory plasma transudation and restoration of normovolemia $(3,22)$. Thus, the circulatory consequences of placental transfusion include both intravascular hypervolemia and subsequent expansion of the extravascular space. Many of the pathophysiologic complications of placental transfusion are a result of both phenomena $(18,19)$. Our intent was to induce hypervolemia and then study GI blood flow and regulation of $\mathrm{O}_{2}$ transport during the transition from intravascular to extravascular volume expansion, as this would most closely mimic the condition in the neonate. One limitation in this analogy is that in placental transfusion, the adaptation process to hypervolemia occurs as the neonatal circulation is making the transition from intra- to extrauterine life, whereas in the current study, the piglet cardiovascular status is relatively established and stable.

The pretransfusion blood volume was similar to that previously reported in neonatal piglets (14). One hour after transfu- sion, measured blood volume had increased 19\%. Each animal had been transfused a sufficient volume of whole blood to expand its pretransfusion blood volume by $26-28 \%$. The smaller measured increase, coupled with the rise in hematocrit, indicates that plasma transudation and hemoconcentration had occurred following transfusion. At the completion of the study, blood volume had returned nearly to the pretransfusion level. We did not specifically measure the volume of the extravascular space during the study, and cannot unequivocally conclude that expansion of this space in the GI tract occurred as the intravascular blood volume declined. However, the sequential changes in blood volume and hematocrit do indicate that fluid transudation did occur, so that we assume that expansion of the extravascular, or interstitial space, did occur following transfusion. In the human infant, this degree of blood volume expansion has been shown to be associated with ultrastructure changes in capillaries, indicating a shift of volume from the intra- to extravascular space (20).

The final hematocrit determination suggests that a loss of red blood cells had occurred following transfusion, as the expected consequences of hypervolemia and hemoconcentration would be a rise in hematocrit (3). There was no microscopic evidence of hemolysis. However, blood replacement and catheter flushing, which followed each phlebotomy for study samples, likely resulted in replacement of plasma in excess of red blood cells and reduction in hematocrit. The average hematocrit used for blood replacement was $22 \pm 2 \%$, which was less than the pre- or posttransfusion hematocrit. The femoral artery and portal vein catheters were flushed with $0.5 \mathrm{ml}$ of $0.9 \%$ saline after each sampling, and the left ventricle catheter was flushed with $2 \mathrm{ml}$ of $0.9 \%$ saline after each microsphere injection. Thus, a minimum of $10 \mathrm{ml}$ of $0.9 \%$ saline flush was administered prior to the last hematocrit determination. Alternatively, it is feasible that sequestration of red blood cells in the spleen and/or liver may have altered the circulating red cell mass.

Blood volume expansion resulted in a $17 \%$ decrease in cardiac output, while mean arterial blood pressure was slightly increased and heart rate was unchanged. To.reconcile these observations would require that stroke volume decreased following transfusion. There are two plausible reasons for the observed reduction in cardiac output. First, some element of cardiac failure may have occurred in response to rapid blood volume expansion, and thus probable preload augmentation. The response of the neonatal myocardium to volume expansion undergoes rapid improvement in the first weeks of life (10) and the piglet baroreceptor response is incompletely developed before $1 \mathrm{wk}$ of age (5). The degree of blood volume expansion administered in this study may have exceeded the adaptive capacity of the piglet myocardium, with the net effect being cardiac decompensation. Second, the reduction in cardiac output may have been a physiologic response to the increase in arterial $\mathrm{O}_{2}$ content $\left(\mathrm{CaO}_{2}\right)$ which was observed after transfusion. Within the range of normal blood viscosity, cardiac output and $\mathrm{CaO}_{2}$ maintain a reciprocal relationship, such that their product (cardiac output $\times \mathrm{CaO}_{2}=$ systemic $\mathrm{O}_{2}$ delivery) is maintained (12). We observed a $13 \%$ increase in $\mathrm{CaO}_{2}$ following transfusion, and pre- and posttransfusion values for systemic $\mathrm{O}_{2}$ delivery were not significantly different (pre: $40.0 \mathrm{ml} \mathrm{O} / \mathrm{kg} / \mathrm{min}$; post: $38.2 \mathrm{ml} \mathrm{O} / \mathrm{kg} / \mathrm{min}$, NS). This maintenance of systemic $\mathrm{O}_{2}$ delivery would suggest that cardiac failure had not occurred following transfusion. The effect of placental transfusion on human neonatal cardiac output or systemic $\mathrm{O}_{2}$ delivery is not known.

Total and regional GI blood flow were not affected by volume expansion. In a previous study, Kotagal et al. (11) described a similar response in newborn dogs subjected to transfusion with whole blood. GI $\mathrm{O}_{2}$ delivery, the conductive phase of $\mathrm{GI} \mathrm{O}_{2}$ transport whereby oxygen is delivered to the capillary level in the GI tract (7), was not altered by volume expansion. Conversely, the diffusion phase of $\mathrm{GI}_{2}$ transport, $\mathrm{O}_{2}$ extraction (7), was significantly reduced following transfusion. $\mathrm{O}_{2}$ extraction 
describes the diffusion of oxygen from capillaries to cells and is dependent on capillary surface area available for metabolite exchange and capillary-to-cell distance $(6,7,21)$. It appears that disruption of $\mathrm{GI}_{2}$ transport occurs following volume loading and is localized in the microcirculation of the GI tract.

Previous work has demonstrated that volume expansion alters the physical dimensions of the intestinal interstitium $(1,13)$. Specifically, volume loading results in an increased capillary filtration rate, physical enlargement of the interstitial space, and a reversal of net water flux favoring net water secretion from the mucosal and serosal surfaces $(1,13)$. Furthermore, Peitra et al. (20) demonstrated that placental transfusion resulted in alteration of capillary morphology in the dermis of the human neonate. Regulation of $\mathrm{GI} \mathrm{O}_{2}$ extraction involves control of capillary perfusion and capillary-to-cell distance; thus, it is feasible that a physical disruption of the capillaries and interstitium could disrupt control of $\mathrm{O}_{2}$ extraction. At the present this explanation remains entirely speculative, and we are unable to conclude as to the mechanisms responsible for the fall in $\mathrm{O}_{2}$ extraction after transfusion.

Because $\mathrm{GI} \mathrm{O}_{2}$ extraction decreased and GI blood flow was unchanged $1 \mathrm{~h}$ after transfusion, $\mathrm{O}_{2}$ consumption by the GI tract decreased. It is difficult to ascertain the functional importance of this decrease in $\mathrm{GI}_{2}$ consumption, since the level of hypoxemia at which tissue damage might occur is not known. In the human newborn, placental transfusion has not been directly associated with GI pathology (22); however, polycythemia, often the consequence of hypervolemia and subsequent hemoconcentration $(3,22)$, has been implicated in the pathogenesis of necrotizing enterocolitis (8). It is conceivable, based on the present data, that the events which often preceed the polycythemic state (i.e. hypervolemia and plasma transudation) are equally responsible for the development of hypoxic tissue damage in the GI tract, resulting in necrotizing enterocolitis.

The intention of feeding the transfused animals was to determine if volume expansion and subsequent restoration of normovolemia altered the capacity of the GI tract to respond to a feeding stimulus. Feeding increases the oxidative requirements of the GI tract $(2,17)$ and previous work in the piglet has demonstrated that the postprandial GI $\mathrm{O}_{2}$ consumption is $72 \pm$ $4 \%$ higher than the preprandial value (17). In the present study, the postprandial increase in the $\mathrm{GI} \mathrm{O}_{2}$ consumption was quantitatively and qualitatively similar to that described in the normal piglets (17). During the study period a continual reduction in blood volume was occurring, so that each postprandial measurement may have been made under different conditions. We interpret this to suggest that volume expansion, to the degree induced, and subsequent restoration of blood volume, does not impair the normal postprandial increase in $\mathrm{GI}_{2}$ consumption.

In summary, $1 \mathrm{~h}$ after rapid volume expansion with whole blood, GI $\mathrm{O}_{2}$ transport and $\mathrm{O}_{2}$ consumption decreased. This decrease was localized in the GI microcirculation and did not involve compromise in mesenteric blood flow. When presented with feeding stimulus, animals recovering from hypervolemia appeared capable of increasing $\mathrm{GI} \mathrm{O}_{2}$ consumption.

Acknowledgements. The authors thank Mr. Raymond Petit and Ms. Carol Calista for their excellent technical assistance, and Ms. Debbie Schaffner for secretarial assistance.

\section{REFERENCES}

1. Duffy PA, Granger DN, Taylor AE 1978 Intestinal secretion induced by volume expansion in the dog. Gastroenterology 75:413

2. Edelstone DI, Holzman IR 1981 Gastrointestinal tract $\mathrm{O}_{2}$ uptake and regional blood flow during digestion in conscious newborn lambs. Am J Physiol 241:G289

3. Gairdner D, Marks J, Roscoe JD, Brettell RI 1958 The fluid shift from the vascular compartment immediately after birth. Arch Dis Child 33:489

4. Gallavan RH, Chou CC, Kvietys PR, Sit SP 1980 Regional blood flow during digestion in the conscious dog. Am J Physiol 238: $\mathrm{H} 220$

5. Gootman N, Gootman PM, Buckley NM, Cohen MI, Levine MI, Spielberg R 1972 Central vasomotor regulation in the newborn piglet. Am J Physiol 222:994

6. Granger DN, Kvietys PR, Perry MA 1982 Role of exchange vessels in the regulation of intestinal oxygenation. Am J Physiol 242:G570

7. Granger HJ, Nyhof RA 1982 Dynamics of intestinal oxygenation: interaction between oxygen supply and uptake. Am J Physiol 243:G91

8. Hakanson DO, Oh W 1977 Necrotizing enterocolitis and hyperviscosity in the newborn infant. J Pediatr 90:458

9. Heymann MA, Payne BD, Hoffman JIE, Rudolph AM 1977 Blood flow measurements with radionuclide-labelled particles. Prog Cardiovasc Dis 20:55

10. Klopfenstein HS, Rudolph AM 1978 Postnatal changes in the circulation and responses to volume loading in sheep. Circ Respir 42:839

11. Kotagal UR, Kennan WJ, Reuter JH, Steichen JJ, Kleinman LI 1977 Regional blood flow in polycythemia and hypervolemia. Pediatr Res 11:394A (abstr)

12. Leblanc MH, Pate K 1984 Effect of polycythemia on vascular volume in the newborn dog. Am J Physiol 246:H830

13. Lee JS 1983 Intestinal transudation, secretion, and lymph flow during volume expansion in the rat. Am J Physiol 244:G688

14. Linderkamp O, Betke K, Guntmer M, Jap CH, Riegel KP, Walser K 1981 Blood volume in newborn piglets: effects of time of natural cord rupture, intra-uterine growth retardation, asphyxia, and prostaglandin-induced prematurity. Pediatr Res 15:53

15. Linderkamp O, Holthausen H, Sifert J, Butenandt I, Tiegel KP 1977 Accuracy of blood volume estimations in critically ill children using ${ }^{125}$ I-labelled albumin and ${ }^{\mathrm{SI}} \mathrm{Cr}$ labelled red cells. Eur J Pediatr 125:143

16. Maxwell LC, Shepherd AP, Riedel GL 1982 Vasodilation for altered perfusion pressure moves $15 \mu \mathrm{M}$ spheres trapped in the gut wall. Am J Physiol 243:H123

17. Nowicki PT, Stonestreet BS, Hansen NB, Yao AC, Oh W 1983 GI blood flow and $\mathrm{O}_{2}$ consumption after feeding in awake piglets. Am J Physiol 245:G697

18. Oh W, Oh MA, Lind J 1966 Renal function and blood volume in newborn infants related to placental transfusion. Acta Paediatr Scand 55:197

19. Oh W, Wallgren G, Hansen JS, Lind J 1967 The effects of placental transfusion on respiratory mechanics of normal term infants. Pediatrics 40:6

20. Peitra GG, D'Amodio MD, Leventhal MM, Oh W, Braudo JL 1968 Electron microscopy of cutaneous capillaries of newborn infants: Effects of placental transfusion. Pediatrics 42:678

21. Shepherd AP 1982 Rise of capillary recruitment in the regulation of intestinal oxygenation. Am J Physiol 242:G435

22. Yao AC, Lind J 1974 Placental transfusion. Am J Dis Child 127:128 